\title{
EFFECT OF DIESEL OIL ON GILL ENZYMES OF ENERGY METABOLISM, ANTIOXIDANT DEFENSE AND ARGINASE OF THE GASTROPOD Nacella concinna (STREBEL 1908) FROM KING GEORGE ISLAND, ANTARCTICA
}

http://dx.doi.org/10.4322/apa.2014.080

\author{
Feijó de Oliveira, Mํ․; Rodrigues Júnior, E¹.; Gannabathula, S. V².; \\ Suda, C. N. K².; Donatti, L'.; Lavrado, H. P.; Rodrigues, E2,* \\ 1'Departamento de Biologia Celular, Universidade Federal do Paraná - UFPR, Centro Politécnico, s/n, \\ Jardim das Américas, CEP 81990-970, Curitiba, PR, Brazil
}

${ }^{2}$ Instituto Básico de Biociências, Universidade de Taubaté - UNITAU, Av. Tiradentes, 500, Centro, CEP 12030-180, Taubaté, SP, Brazil 32Departamento de Biologia Marinha, Universidade Federal do Rio de Janeiro - UFRJ, Av. Carlos Chagas Filho, 373 , Ilha do Fundão, CEP 21941-902, Rio de Janeiro, RJ, Brazil

*e-mail: rodedson@gmail.com

\begin{abstract}
Raising human impact and pollution in Antarctica has focused studies to verify possible biomarker for environmental monitoring. Nacella concinna is the most conspicuous macro invertebrate of the Antarctic intertidal zone. The diesel oil leakage of icebreaker Bahia Paradise reduced in 50\% N. concinna populations near Palmer Scientific Station. The aim of this study was to verify the effect of diesel oil on activity of enzymes hexokinase, lactate dehydrogenase, citrate synthase, malate dehydrogenase, glucose-6-phoshate dehydrogenase, glutathione reductase, catalase, superoxide dismutase and arginase of Nacella concinna gills. Specimens collected in Keller Peninsula were maintained in mini aquariums containing $1 \%$ or $5 \%$ of diesel oil. The results showed that the enzymes arginase, phosphofructokinase and catalase are potential biomarkers for diesel oil pollution.
\end{abstract}

Keywords: Antarctica, Nacella concinna, diesel oil, biomarkers

\section{Introduction}

The gastropod Nacella concinna is the most conspicuous macro invertebrate in the Antarctic seas, with an ample geographic distribution, and has been postulated as a sentinel organism due to its capacity for bioaccumulation of heavy metals (Ahn et al., 2002). The exposure to climate to the terrestrial environment when the tide recedes, freezing in winter, friction of the ice on sediments and rocks, reduction of salinity due to the entry of melt waters in to the sea and the exposure to ultraviolet radiation have been considered the principal stress factors on the organisms that inhabit the Antarctic intertidal zones (Davenport, 2001; Peck et al., 2006; Barnes \& Peck, 2008; Obermüller et al., 2011).

Human presence in the Antarctic has increased significantly during the last few decades and has accelerated by international scientific efforts after the International Polar year 1957/58 (Tin et al., 2009). The concerns about the pollution around scientific stations and round the Anchorage locations of shipping vessels was justified after the sinking of the icebreaker Bahia Paradise in 1989, which resulted in the leakage of 600,000L of diesel oil in the Arthur Harbor, Antarctic Peninsula, close to the Palmer Scientific Station (USA) (Kennicutt II et al., 1992). In this case, the gastropod N. concinna population was reduced by $50 \%$ and only partially recovered after one year. Bioassays of $N$. concinna showed that diesel oil could elevate the protein oxidation and the levels of glutathione peroxidase, in addition to reducing the levels of the catalase in the digestive 
gland. Whereas the levels of he dismutase superoxide were not altered (Ansaldo et al., 2005).

The present study aims to verify the effect of diesel oil on the concentrations of the energy metabolism enzymes, the antioxidant defense and metabolism of L-arginine in the gills, as possible biomarkers of the environmental impact.

\section{Materials and Methods}

Specimens of $N$. concinna were collected from the Keller peninsula $\left(62^{\circ} 05^{\prime} 28.8^{\prime \prime} \mathrm{S}\right.$ and $\left.58^{\circ} 24^{\prime} 21.3^{\prime \prime} \mathrm{W}\right)$, close to the Brazilian Antarctic station Commandant Ferraz (EACF), during the period January to March 2011. The experiments were conducted in mini aquariums $(2.5 \mathrm{~L})$ with 10 specimens/aquarium, subjected to thermo-saline condition $0{ }^{\circ} \mathrm{C}$ and $35 \mathrm{psu}$, with $5 \%$ and $1 \%$ diesel oil and control without diesel oil. The bioassays had duration of 8 days, aerated continuously, water changed daily and 12 hours of photoperiod without alimentation. Natural controls were established using specimens that were dissected immediately after the collection. All the tissue samples were frozen in liquid nitrogen for posterior analysis. The homogenates were prepared in the proportion of $1 \mathrm{~g}$ of gill for $10 \mathrm{~mL}$ of buffer Tris-HCL $50 \mathrm{mM}$, pH 7.4, sonicated for 15 seconds, centrifuged at $12,000 \mathrm{xg}$, for 10 minutes, and the supernatants used to determine the activities of the enzymes: hexokinase (HK) (Baldwin et al., 2007); phosphofructokinase (PFK) (Baldwin et al., 2007); lactate dehydrogenase (LDH) (Thuesen et al., 2005); citrate synthase (CS) (Saborowski \& Buchholz, 2002); malate dehydrogenase (MDH) (Childress \& Somero, 1979); glucose-6-phosphate dehydrogenase (G6PDH) (Ciardiello et al., 1995); glutathione reductase (GRED) (Sies et al., 1979); superoxide dismutase (SOD) (Crouch et al., 1981); catalase (CAT) (Regoli et al., 1997); arginase (ARG) (Iyamu et al., 2008). The enzymatic activities were normalized with the concentrations of proteins, determined by the "bicinchoninic acid" (BCA, kit QuantiPro - Sigma) method.

The statistical analysis was done using Statistica 5.0 for Windows. The results are presented as mean \pm SEM (standard error of the mean). Statistical comparison between groups was done using three way ANOVA, followed by the multiple pairwise Tukey "a posteriori" comparison test. Levene's test was used to determine the homoscedasticity of the data, and a $\log \mathrm{x}$ correction was applied when required. Differences were considered significant for $\mathrm{p}<0.05$.

\section{Results}

The effect of two different concentrations of diesel oil (D1\% and $\mathrm{D} 5 \%$ ) on the gill levels of $\mathrm{HK}, \mathrm{PFK}, \mathrm{LDH}, \mathrm{CS}, \mathrm{MDH}$, G6PDH, GRED, CAT, SOD and ARG, in the thermo-saline 0-35 experimental condition are summarized in Figure 1. The increase in the levels of HK, GRED and SOD, as well as reduction of $\mathrm{MDH}$ and $\mathrm{G} 6 \mathrm{PDH}$, observed in the presence of diesel oil were not significant. The PFK levels were upregulated in the presence of diesel oil 5\% (D5\%), whereas CAT with D5\% was downregulated. The levels of ARG were significantly upregulated in the presence of $\mathrm{D} \% 5$.

\section{Discussion}

The enzymes LDH, MDH and CS have been used as markers of potential anaerobic and aerobic ATP generators in the cells (Torres \& Somero, 1988) The branchial levels of LDH, $\mathrm{MDH}$ and CS are not influenced by the presence of diesel oil, indicating that the aerobic and anaerobic metabolic pathways may not be influenced by the diesel oil effect in this tissue. The principal glycolytic pathway regulator enzyme PFK levels were upregulated in the presence of diesel oil. The enzymes G6PDH, GRED and SOD, directly or indirectly, participate in the cellular antioxidant defense. G6PDH catalyze reducing reactions of $\mathrm{NADP}^{+}$to $\mathrm{NADPH}+\mathrm{H}^{+}$, GRED reduces glutathione and $\mathrm{SOD}$ decomposes $\mathrm{O}_{2}^{-}$.SOD is often called the primary defense against oxidative stress because superoxide is strong initiator of chain reaction and may the raise in the levels of SOD can be related to the raise of superoxide in the presence of diesel oil. CAT is part of the antioxidant defense enzymes and does the decomposition of $2 \mathrm{H}_{2} \mathrm{O}_{2}$ in $\mathrm{H}_{2} \mathrm{O}$ and $\mathrm{O}_{2}$. It was downregulated in the presence of diesel oil. The levels of ARG were upregulated in the presence of diesel oil. This enzyme participate in the intracellular control of phospo-L-Arginine, nitric oxide and polyamines levels (Wu \& Morris Junior, 1998).

The levels of CS, LDH and SOD are significantly higher in natural control than in experimental control (Figure 1). The elevated levels of SOD in the natural control can be related to this gastropod migration to the intertidal zone during the austral spring and its exposition to more elevated temperature, which could be inducing increase in SOD (Abele et al., 1998). The thermic stress has effect on the energy demand of $N$. concinna and is capable of reducing ATP levels, lift the oxygen consumption and down 

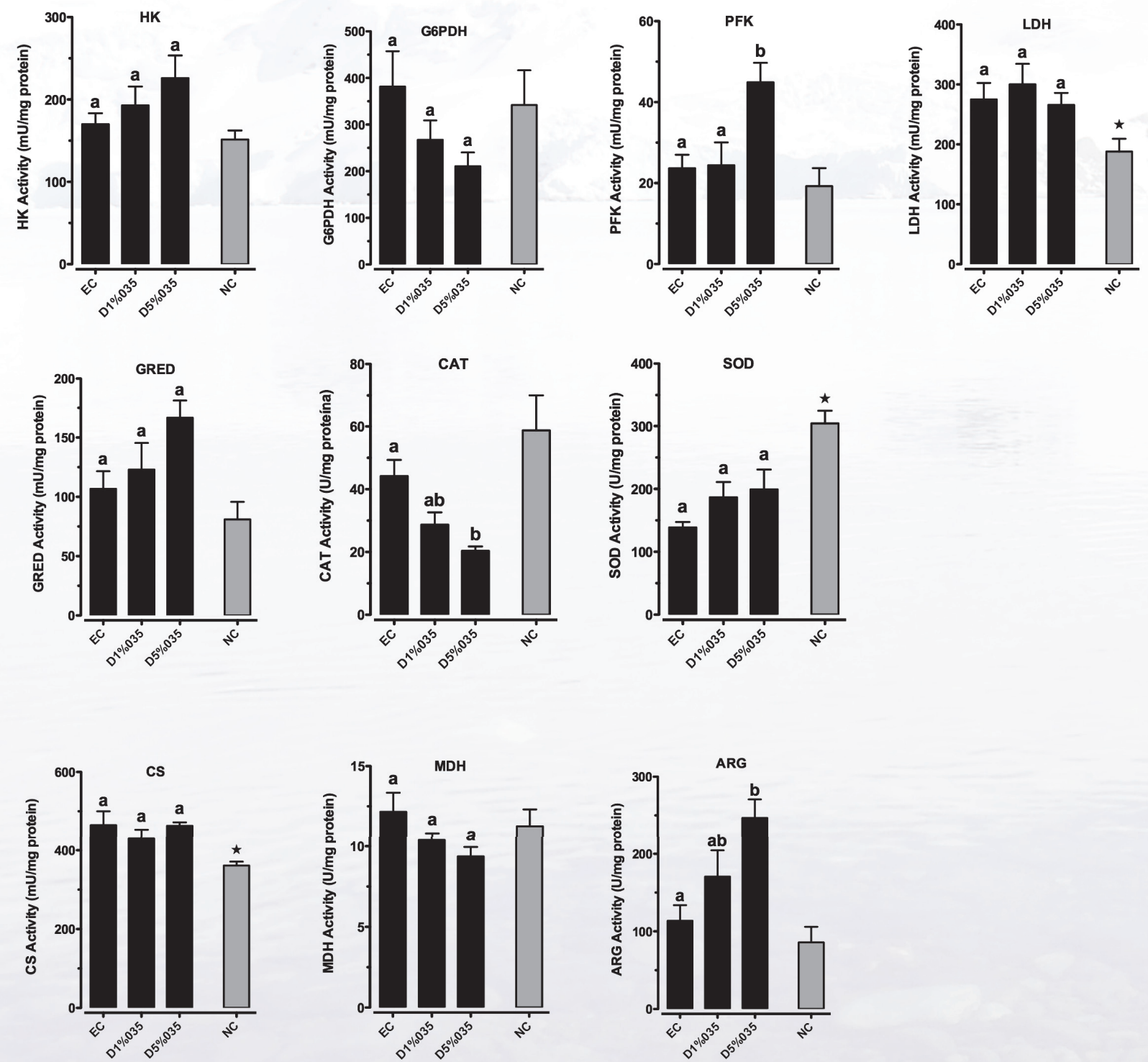

Figure 1. Activity of enzymes hexokinase (HK), phosphofrutokinase (PFK), lactate dehydrogenase (LDH), citrate synthase (CS), malate dehydrogenase $(\mathrm{MDH})$, glucose-6-phosphate dehydrogenase (G6PDH), glutathione reductase (GRED), catalase (CAT), superoxide dismutase (SOD) and arginase (ARG) of Nacella concinna gills. Data are expressed as means \pm SE. Asterisk indicates significant differences between nature control (NC) and experimental control (EC). Different letters indicate differences between treatments.

regulate the CS levels in the foot muscle of this gastropod (Pörtner et al., 1999).

\section{Conclusion}

The elevated levels of enzymes CS, LDH and SOD in gills of nature controls in relation to experimental control (thermosaline condition 0-35), showed that natural stress imposed by the ambient conditions of the intertidal zone is capable of upregulating these enzymes levels. The enzymes ARG, PFK and CAT can be used as potential biomarkers for diesel oil pollution, considering that: a) the natural stress in the intertidal zone was not capable of inducing expressive alterations in these enzymes compared to experimental controls; b) diesel oil induced significant alterations in 
these enzymes levels; c) except PFK, the effect of diesel oil on the ARG and CAT enzymes levels was more intense in the experimental condition of $5 \%$ than at $1 \%$.

\section{Acknowledgements}

This work integrates the National Institute of Science and Technology Antarctic Environmental Research (INCT-
APA) that receives scientific and financial support from the National Council for Research and Development (CNPq process: $n^{\circ}$ 574018/2008-5) and Carlos Chagas Research Support Foundation of the State of Rio de Janeiro (FAPERJ $n^{\circ}$ E-16/170.023/2008). The authors also acknowledge the support of the Brazilian Ministries of Science, Technology and Innovation (MCTI), of Environment (MMA) and InterMinistry Commission for Sea Resources (CIRM).

\section{References}

Abele, D.; Burlando, B.; Viarengo, A. \& Portner, H.-O. (1998). Exposure to elevated temperatures and hydrogen peroxide elicits oxidative stress and antioxidant response in the Antarctic intertidal limpet Nacella concinna. Comparative Biochemistry and Physiology Part B: Biochemistry and Molecular Biology, 120(2): 425-35.

Ahn, I.Y.; Kim, K.W. \& Choi, H.J. (2002). A baseline study on metal concentrations in the Antarctic limpet Nacella concinna (Gastropoda: Patellidae) on King George Island: Variations with sex and body parts. Marine Pollution Bulletin, 44(5): 424-31.

Ansaldo, M.; Najle, R. \& Luquet, C.M. (2005). Oxidative stress generated by diesel seawater contamination in the digestive gland of the Antarctic limpet Nacella concinna. Marine Environmental Research, 59(4): 381-90.

Baldwin, J.; Elias, J.P.; Wells, R.M.G. \& Donovan, D.A. (2007). Energy metabolism in the tropical abalone, Haliotis asinina Linné: Comparisons with temperate abalone species. Journal of Experimental Marine Biology and Ecology, 342(2): $213-25$.

Barnes, D.K.A. \& Peck, L.S. (2008). Vulnerability of Antarctic shelf biodiversity to predicted regional warming. Climate Research, 37(2-3): 149-63.

Childress, J.J. \& Somero, G.N. (1979). Depth-related enzymic activities in muscle, brain and heart of deep-living pelagic marine teleosts. Marine Biology, 52(3): 273-83

Ciardiello, M.A.; Camardella, L. \& Di Prisco, G. (1995). Glucose-6-phosphate dehydrogenase from the blood cells of two antarctic teleosts: Correlation with cold adaptation. Biochimica et Biophysica Acta - Protein Structure and Molecular Enzymology, 1250(1): 76-82.

Crouch, R.K.; Gandy, S.E.; Kimsey, G.; Galbraith, R.A.; Galbraith, G.M. \& Buse, M.G. (1981). The inhibition of islet superoxide dismutase by diabetogenic drugs. Diabetes, 30: 235-41.

Davenport, J. (2001). Meltwater effects on intertidal Antarctic limpets, Nacella concinna. Journal of the Marine Biological Association of the UK, 81: 643-9.

Iyamu, E.W.; Asakura, T. \& Woods, G.M. (2008). A colorimetric microplate assay method for high-throughput analysis of arginase activity in vitro. Analytical Biochemistry, 383(2): 332-4.

Kennicutt II, M.C.; McDonald, T.J.; Denoux, G.J. \& McDonald, S.J. (1992). Hydrocarbon contamination on the antarctic peninsula. II. Arthur Harbor inter- and subtidal limpets (Nacella concinna). Marine Pollution Bulletin, 24(10): 506-11.

Obermüller, B.E.; Morley, S.A.; Clark, M.S.; Barnes, D.K.A. \& Peck, L.S. (2011). Antarctic intertidal limpet ecophysiology: A winter-summer comparison. Journal of Experimental Marine Biology and Ecology, 403(1-2): 39-45.

Peck, L.S.; Convey, P. \& Barnes, D.K.A. (2006). Environmental constraints on life histories in Antarctic ecosystems: Tempos, timings and predictability. Biological Reviews of the Cambridge Philosophical Society, 81(1): 75-109.

Pörtner, H.O.; Peck, L.; Zielinski, S. \& Conway, L.Z. (1999). Intracellular pH and energy metabolism in the highly stenothermal Antarctic bivalve Limopsis marionensis as a function of ambient temperature. Polar Biology, 22(1): 17-30. 
Regoli, F.; Principato, G.B.; Bertoli, E.; Nigro, M. \& Orlando, E. (1997). Biochemical characterization of the antioxidant system in the scallop Adamussium colbecki, a sentinel organism for monitoring the Antarctic environment. Polar Biology, 17(3): 251-8.

Saborowski, R. \& Buchholz, F. (2002). Metabolic properties of Northern krill, Meganyctiphanes norvegica, from different climatic zones. II. Enzyme characteristics and activities. Marine Biology, 140(3): 557-65.

Sies, H.; Koch, O.R.; Martino, E. \& Boveris, A. (1979). Increased biliary glutathione disulfide release in chronically ethanoltreated rats. FEBS Letters, 103(2): 287-90.

Thuesen, E.V.; McCullough, K.D. \& Childress, J.J. (2005). Metabolic enzyme activities in swimming muscle of medusae: is the scaling of glycolytic activity related to oxygen availability? Journal of the Marine Biological Association of the UK, 85(03): 603-11.

Tin, T.; Fleming, Z.L.; Hughes, K.A.; Ainley, D.G.; Convey, P.; Moreno, C.A.; Pfeiffer, S.; Scott, J. \& Snape, I. (2009). Impacts of local human activities on the Antarctic environment. Antarctic Science, 21(1): 3-33.

Torres, J.J. \& Somero, G.N. (1988). Metabolism, enzymic activities and cold adaptation in Antarctic mesopelagic fishes. Marine Biology, 98(2): 169-80.

Wu, G. \& Morris Junior, S.M. (1998). Arginine metabolism: nitric oxide and beyond. Biochemical Journal, 336: 1-17. 